Gut, 1985, 26, 55-59

\title{
Histological diagnosis of chronic inflammatory bowel disease in childhood
}

\author{
S K F CHONG, A J BLACKSHAW, S BOYLE, \\ C B WILLIAMS, AND J A WALKER-SMITH
}

From the Departments of Child Health, Gastroenterology, and Histopathology, St Bartholomew's Hospital, London

SUMMARY One hundred and four children were initially assessed by clinical, radiological, and endoscopic criteria as chronic inflammatory bowel disease. All were assessed independently using precise histological diagnostic criteria. Fifty eight patients were diagnosed as Crohn's disease, 25 as ulcerative colitis, 15 remained provisionally categorised as indeterminate colitis and six proved to be normal. Diagnostic granulomas were found in $36 \%$ of endoscopic biopsies from the 58 children with Crohn's disease. This appears to be an underestimate as only four of 14 children with granulomatous Crohn's disease operated on had granulomas on endoscopic biopsy. This study shows that there is a spectrum of histological appearances in endoscopic biopsies in chronic inflammatory bowel disease in childhood ranging from definite Crohn's disease to definite ulcerative colitis with indeterminate features in between. Accurate histological diagnosis of chronic inflammatory bowel disease is dependent upon either multiple endoscopic biopsies or assessment of a surgically resected specimen.

At present in the absence of known aetiology, histology remains the final arbiter of the nature of an inflammatory bowel disease when a surgically resected specimen is available for examination. ${ }^{1}$ Because of the limitations in sampling of colonic mucosa imposed by the nature of endoscopic mucosal biopsy specimens, we have investigated the value of the concept of a spectrum of histological appearances. ${ }^{2}$ As the selection of the histological criteria used to place biopsies within this spectrum is bound to arouse controversy, endoscopic biopsies and operative specimens of children with chronic inflammatory bowel disease have been examined to assess the merits of a system of histological diagnostic criteria for classification of chronic inflammatory bowel disease in childhood.

\section{Methods}

PATIENTS

Between 1972 and 1982, a total of 104 children, referred from various district hospitals to St Bartholomew's Hospital, formed the basis of this

Address for correspondence: Dr S K F Chong, Department of Child Health, St Bartholomew's Hospital, London EC1A 7BE.

Received for publication 10 April 1984 study. The children with chronic inflammatory bowel disease were diagnosed on clinical, radiological and endoscopic criteria. Infective colitides were excluded by the relevant bacteriological or serological investigation in all patients. Endoscopic mucosal biopsies from the colon were reviewed for the presence of granulomas. The histological assessment was based on the concept that an apparent range of inflammatory changes within a continuous spectrum exists. In each biopsy the histological features were noted, and the significance attached to them listed. The histological features were then placed in a spectrum of certainty ranging from definite Crohn's disease to definite ulcerative colitis. For simplicity this spectrum was divided into the five categories shown below:

(a) Definite ulcerative colitis

(i) Acute inflammation with severe crypt distortion and diffuse goblet cell depletion (mucus depletion). Inflammation is diffuse and solely mucosal. Vascularity is increased.

(b) Probable ulcerative colitis

(i) Diffuse mucosal inflammation with only mild or moderate crypt distortion, mucosal atrophy or mucus depletion. (ii) Diffuse acute and chronic inflammation with increased vascularity but little 
mucus depletion - suggesting resolving phase.

(c) Indeterminate colitis

Some features suggestive of both ulcerative colitis and Crohn's disease.

(d) Probable Crohn's disease

One or more of the following features present: (i) Focal inflammation. (ii) Submucosal or transmural inflammation. (iii) Lyphocytic aggregates (without germinal centres). (iv) Mucus retention in the presence of more than minimal acute inflammation. (e) Definite Crohn's disease

Any or all of the above (d) together with either (i) Non-caseating granulomas, or (ii) fissuring ulceration (in surgically resected specimens).

This histological opinion was then incorporated as one element of the final clinical diagnosis of the inflammatory bowel disease. This final diagnosis was based upon the clinical, radiological, and endoscopic features as well as the histological features described above. The radiological criteria taken to be indicative of Crohn's disease were: aphthoid ulceration, deep fissuring ulcers, asymmetric involvement both longitudinally with 'skip lesions' or transversely with normal bowel adjacent to ulcers, pseudo-diverticula formation and spontaneous entero-enteric fistula; in the large bowel, or in the small bowel with any change in the large bowel. Changes typical of ulcerative colitis were a granular mucosa with loss or absent haustration which was symmetrical and in continuity, and confluent shallow ulceration in an acute attack. ${ }^{3}$ The endoscopic criteria for Crohn's disease were discrete aphthoid ulceration with asymmetrical mucosal involvement, stricture formation and pseudopolyps. The endoscopic features of ulcerative colitis were hyperaemia with friability, micro-ulcerations and pseudopolyps. ${ }^{4}$

The individual cases which fall into an intermediate category were called indeterminate colitis, reflecting the inability within the current criteria to make a clear separation. 'Indeterminate colitis' is to be regarded as a holding category rather than a diagnostic label. The patients were classified into three groups, namely, Crohn's disease, ulcerative colitis, and an indeterminate group, using the diagnostic criteria outlined. All histological sections and subsequent bowel resections were then examined by two of us (AJB and SB) who were unaware of the clinical, endoscopic, or radiological details.

\section{Results}

Based on clinical, radiological, and endoscopic investigations as outlined above, the 104 children were categorised into three groups initially (Table 1). Seventy children were in group I (Crohn's disease), 24 in group II (ulcerative colitis) and 10 in group III (unclassified). After histological review of the endoscopic mucosal biopsies, 55 of the 70 patients in group I were finally diagnosed as Crohn's disease, two were ulcerative colitis and four cases were histologically normal. Twenty of the 24 children in group II were finally diagnosed as ulcerative colitis, one child had the diagnosis changed to Crohn's disease after histological investigation, three were histologically indeterminate and none were normal. Of the 10 children in group III (unclassified), the diagnosis established on histology showed that three had ulcerative colitis, two had Crohn's disease, three had indeterminate colitis and two were normal.

\section{ENDOSCOPIC BIOPSIES}

Analyses of the histological diagnosis of the 104 endoscopic biopsies resulted in a diagnosis of Crohn's disease in 58 children, ulcerative colitis in 25 , indeterminate colitis in 15 and normal histology in six (Table 2)

Classified epithelioid granulomata were present in 21 of the patients with Crohn's disease. This overall proportion of $36 \%$ is comparable with the $25 \%$ of diagnostic granulomata on endoscopic biopsies recorded by Geboes et al in adult patients. ${ }^{5}$ This feature, together with the other histological aggregates, make the definitive diagnosis tenable. The

Table 1 Classification of 104 children assessed to have chronic inflammatory bowel disease at initial and final diagnosis using the histological diagnostic criteria.

\begin{tabular}{|c|c|c|c|c|c|}
\hline \multicolumn{2}{|l|}{ Initial diagnosis } & \multicolumn{4}{|c|}{ Final histological diagnosis } \\
\hline $\begin{array}{l}\text { Diagnosis based on clinical features, } \\
\text { radiology and endoscopy }\end{array}$ & $\begin{array}{l}\text { Patients } \\
\text { (no) }\end{array}$ & $\begin{array}{l}\text { Ulcerative } \\
\text { colitis }\end{array}$ & $\begin{array}{l}\text { Indeterminate } \\
\text { colitis }\end{array}$ & $\begin{array}{l}\text { Crohn's } \\
\text { colitis }\end{array}$ & Normal \\
\hline Group I (Crohn's disease) & 70 & 2 & 9 & 55 & 4 \\
\hline Group II (ulcerative colitis) & 24 & 20 & 3 & 1 & 0 \\
\hline Group III (unclassified) & 10 & 3 & 3 & 2 & 2 \\
\hline Total & 104 & 25 & 15 & 58 & 6 \\
\hline
\end{tabular}


Table 2 Analysis of endoscopic biopsies and operative specimens of children with chronic inflammatory bowel disease.

\begin{tabular}{|c|c|c|c|c|c|c|}
\hline \multirow[b]{2}{*}{ Final diagnosis } & \multirow{2}{*}{$\begin{array}{l}\text { Patients } \\
\text { (no) }\end{array}$} & \multicolumn{2}{|c|}{ Endoscopic biopsy } & \multirow{2}{*}{$\begin{array}{l}\text { Patients } \\
\text { (no) }\end{array}$} & \multicolumn{2}{|c|}{ Operative specimen } \\
\hline & & Probable & Definite & & Probable & Definite \\
\hline Ulcerative colitis & 25 & $17(68 \%)$ & $8(32 \%)$ & 5 & $0(0 \%)$ & $5(100 \%)$ \\
\hline Crohn's disease & 58 & $37(64 \%)$ & $21(36 \%)$ & 17 & $3(18 \%)$ & $14(82 \%)$ \\
\hline Indeterminate colitis & 15 & & & & & \\
\hline
\end{tabular}

remaining $64 \%$ had the histological features of probable Crohn's disease.

Eight of the 25 children with the final diagnosis of ulcerative colitis had definite histological changes to support this diagnosis $(32 \%)$, in two patients diagnosed by all the other criteria to be ulcerative colitis focal aggregates of chronic inflammatory cells next to crypts undergoing disruption were seen. Such foci were considered indefinite or only possible granulomas. These two patients together with the other 15 were diagnosed on the basis of histological features as probably ulcerative colitis.

INDETERMINATE COLITIS

The remaining 15 children with definite evidence of chronic inflammation on endoscopic biopsy, but not histologically classifiable as Crohn's disease or ulcerative colitis, were categorised as indeterminate colitis.

\section{OPERATIVE SAMPLES}

On studying the operative specimens, 17 children were diagnosed as Crohn's disease using the diagnostic criteria (Table 3), 14 children (Nos 1-14) had the definite histological features of Crohn's disease which included non-caseating granulomata. In nine of these children, (Nos 3, 4, 5, 6, 9, 10, 11, $12,13)$, however, no granulomas were seen in preoperative endoscopic biopsies although granulomas were present in surgically resected specimens. This experience illustrates the importance of sampling and repeating biopsies in equivocal cases. The availability of larger amounts of tissue in surgically resected specimens in general enables a more confident diagnosis to be made in many cases. The operative specimens of all five children with ulcerative colitis on histological examination showed evidence of definite ulcerative colitis. Only two of the five children were classified as definite ulcerative colitis on endoscopic biopsy before surgery.

The presence of diagnostic granulomata in only $36 \%$ of endoscopic biopsies in children considered finally to have Crohn's disease is probably an under-estimation owing to sampling. Examination of the surgical specimens revealed granulomas in 14
$(82 \%)$ of the 17 children operated on for Crohn's disease although only five of the 17 had granulomas on endoscopic biopsy. Similarly, definite histological evidence of ulcerative colitis was seen in only $32 \%$ of endoscopic biopsies.

\section{Discussion}

This study indicates that the concept of a spectrum of histological appearances in chronic inflammatory bowel disease in childhood is useful and is convenient for practical assessment. This is particularly true in the early histological appearance of children with Crohn's disease when the definitive criteria may not be present. From the point of view of histological assessment, particularly of mucosal biopsies, which are small in size, the histopathologist is faced with an apparent range of inflammatory changes falling within a continuous spectrum. The approach outlined here is not intended to imply that inflammatory bowel disease is genuinely a continuous spectrum of a single disease. It reflects only the difficulty of making a confident diagnosis by extrapolation from a very restricted sample of the organ in question.

Analysis of the histological findings of this study has shown that Crohn's disease composes $60 \%$ of paediatric inflammatory bowel disease as seen at St. Bartholomew's Hospital over the last 10 years. This finding conforms with the increasing incidence of this disease in Britain, ${ }^{6}$ but may well be related to our assiduous search for Crohn's disease in a younger population. In contrast, the lower incidence of childhood ulcerative colitis $(25 \%)$ diagnosed by our histological criteria is unusual as the incidence in the last decade has been higher than Crohn's disease.

Our finding of an indeterminate colitis in $15 \%$ of the total number of children seen with chronic inflammatory bowel disease compares well with the results of previous clinical evaluations which suggest that Crohn's disease and ulcerative colitis can be successfully distinguished in about $80 \%$ of patients with inflammatory bowel disease. ${ }^{7}$

Until the aetiology of Crohn's disease and ulcerative colitis are established, diagnosis must be based 
Table 3 Clinical and operative details of 17 patients with Crohn's disease.

\begin{tabular}{|c|c|c|c|c|c|c|}
\hline Patients & $\begin{array}{l}\text { Granuloma on } \\
\text { endoscopic } \\
\text { biopsies }\end{array}$ & $\begin{array}{l}\text { Age at } \\
\text { onset of } \\
\text { symptoms }\end{array}$ & $\begin{array}{l}\text { Age at } \\
\text { operation }\end{array}$ & $\begin{array}{l}1^{\circ} \text { and } 2^{\circ} \\
\text { indications }\end{array}$ & $\begin{array}{l}\text { Bowel } \\
\text { involvement }\end{array}$ & $\begin{array}{l}2 \text { years post } \\
\text { operative course }\end{array}$ \\
\hline 1. $\mathrm{KB}$ & + & 8 & $\begin{array}{l}12 \frac{1}{2} \\
R . \text { colectomy }+ \\
\text { Terminal ileum } \\
\text { resection }\end{array}$ & Obstruction & Terminal ileum & Off steroids \\
\hline 2. SF & + & 12 & $\begin{array}{l}14 \\
\text { Total colectomy }\end{array}$ & $\begin{array}{l}\text { Failed med. R } \\
<3 \%\end{array}$ & $\begin{array}{l}\text { Terminal ileum }+ \\
\text { Entire colon }\end{array}$ & $\begin{array}{l}\text { Recurrence } \\
\text { On steroids }\end{array}$ \\
\hline 3. JC & - & $13 \frac{1}{2}$ & $\begin{array}{l}14 \\
\text { R. colectomy + } \\
\text { Terminal ileum } \\
\text { resection }\end{array}$ & Obstruction & $\begin{array}{l}\text { Terminal ileum }+ \\
\text { R. colon }\end{array}$ & Well \\
\hline 4. DB & - & $10 \frac{1}{2}$ & $\begin{array}{l}14 \\
\text { Total colectomy }\end{array}$ & Failed med. $\mathbf{R}$ & $\begin{array}{l}\text { Small intestine }+ \\
\text { Entire colon }\end{array}$ & $\begin{array}{l}\text { Recurrence } \\
\text { On steroids }\end{array}$ \\
\hline 5. GL & - & 11 & $\begin{array}{l}13 \\
\text { Terminal ileal } \\
\text { resection }\end{array}$ & $\begin{array}{l}\text { Growth retardation } \\
<3 \%\end{array}$ & Terminal ileum & $\begin{array}{l}\text { Recurrence } \\
\text { Prepubertal } \\
\text { re-operated }\end{array}$ \\
\hline 6. AP & - & 10 & $\begin{array}{l}15 \\
R \text {. colectomy } \\
\text { resection }\end{array}$ & Failed med. $\mathbf{R}$ & $\begin{array}{l}\text { Small intestine }+ \\
\text { L. colon }\end{array}$ & $\begin{array}{l}\text { Recurrence } \\
\text { On steroids }\end{array}$ \\
\hline 7. $\mathrm{DL}$ & + & 14 & $\begin{array}{l}15 \\
\text { R. colectomy + } \\
\text { Terminal ileum } \\
\text { resection }\end{array}$ & Obstruction & $\begin{array}{l}\text { R. Colon }+ \\
\text { Terminal ileum }\end{array}$ & $\begin{array}{l}\text { Well } \\
\text { On steroids and } \\
\text { Azathioprine }\end{array}$ \\
\hline 8. NS & + & 11 & $\begin{array}{l}16 \\
\text { colectomy }\end{array}$ & Obstruction & L. colon & $\begin{array}{l}\text { Recurrence } \\
\text { On steroids }\end{array}$ \\
\hline 9. $\mathrm{MH}$ & - & 12 & $\begin{array}{l}\text { Multiple small } \\
\text { intestine } \\
\text { resection }+\end{array}$ & Failed med. R & $\begin{array}{l}\text { Small intestine }+ \\
\text { Entire colon }\end{array}$ & Recurrence \\
\hline 10. CS & - & 12 & $\begin{array}{l}17 \\
\mathbf{R} \text {. colectomy + } \\
\text { Terminal ileum } \\
\text { resection }\end{array}$ & Failed med. R & $\begin{array}{l}\text { Small intestine }+ \\
\text { Entire colon }\end{array}$ & Recurrence \\
\hline 11. DM & - & 14 & $\begin{array}{l}17 \\
\text { Small intestine } \\
\text { resection }\end{array}$ & $\begin{array}{l}\text { Obstruction } \\
<3 \%\end{array}$ & Small intestine & $\begin{array}{l}\text { Well } \\
\text { Pubertal } \\
\text { Off steroids }\end{array}$ \\
\hline 12. $\mathrm{SM}$ & - & 8 & $\begin{array}{l}15 \\
\text { R. colectomy }\end{array}$ & $\begin{array}{l}\text { Failed med. } \mathbf{R} \\
<3 \% \text { prepubertal }\end{array}$ & R. colon & $\begin{array}{l}\text { Recurrence } \\
\text { On steroids }\end{array}$ \\
\hline 13. SW & - & 4 & $\begin{array}{l}10 \frac{1}{2} \\
\text { Total colectomy } \\
\text { and } T I \text { resection }\end{array}$ & Failed med. $\mathbf{R}$ & $R+L$ colon & \\
\hline 14. $\mathrm{GH}$ & + & 9 & $14 \frac{1}{2}$ & $\begin{array}{l}\text { Obstruction } \\
\text { RIF mass }\end{array}$ & $\begin{array}{l}\text { Small intestine + } \\
\text { Entire colon }\end{array}$ & \\
\hline 15. VK & - & $11 \frac{1}{2}$ & $\begin{array}{l}12 \\
\text { Hemicolectomy } \\
\text { and TI resection }\end{array}$ & RIF mass & $\begin{array}{l}\text { Small intestine }+ \\
R \text {. colon }\end{array}$ & \\
\hline 16. IM & - & $12 \frac{1}{2}$ & $\begin{array}{l}14 \frac{1}{2} \\
\text { R. hemicolectomy }\end{array}$ & $\begin{array}{l}\text { Failed med. } R \\
\text { RIF mass }\end{array}$ & $\begin{array}{l}R+L \text { colon } \\
R \text { psoas abcess }\end{array}$ & \\
\hline 17. $\mathrm{CW}$ & - & 14 & $\begin{array}{l}15 \\
\text { R. hemicolectomy }\end{array}$ & Obstruction & $\begin{array}{l}\text { Stricture at } \\
\text { ICV + Terminal } \\
\text { ileum }\end{array}$ & \\
\hline
\end{tabular}

on histological criteria. At present it is only possible to make a final diagnosis of Crohn's disease or ulcerative colitis by either multiple endoscopic biopsies or by histological assessment of resected bowel. In the remaining cases the concept of a histological spectrum is a practical and useful diagnostic aid.

We thank CICRA (Crohn's disease in Childhood
Research Appeal) for supporting Dr S K F Chong, and we also thank Miss Betty Ashley for typing this manuscript.

\section{References}

1 Chong SKF, Bartram CI, Campbell CA, Williams CB, Blackshaw AJ, Walker-Smith JA. Chronic inflammatory 
bowel disease in childhood. Br Med J 1982; 284: 101-3.

2 Price AB. Overlap in the spectrum of non-specific inflammatory bowel disease - 'colitis indeterminate'. $J$ Clin Pathol 1978; 31: 567-77.

3 Bartram CI. Differential diagnosis of inflammatory bowel disease. In: Bartram CI ed. Radiology in inflammatory bowel disease. New York: Marcel Dekker, 1983: 221-58.

4 Cotton PB, Williams CB. Colonoscopy. In: Cotton PB, Williams CB eds. Practical gastrointestinal endoscopy.
Oxford: Blackwell Scientifiic Publications, 1980: 86-127.

5 Geboes K, Vantrappen G. The value of colonoscopy in diagnosis of Crohn's disease. Gastrointest Endosc 1975; 22: 18-23.

6 Chong SKF, Walker-Smith JA. Chronic inflammatory bowel disease in the young. Compr Ther 1982; 8: 27-34.

7 Kirsner JB. Problems in the differentiation of ulcerative colitis and Crohn's disease of the colon: the need for repeated diagnostic evaluation. Gastroenterology 1974; 68: $187-91$. 